AGRICULTURE AND BIOLOGY JOURNAL OF NORTH AMERICA

ISSN Print: 2151-7517, ISSN Online: 2151-7525, doi:10.5251/abjna.2013.4.1.41.47

(C) 2013, ScienceHu $\beta$, http://www.scihub.org/ABJNA

\title{
Decommissioned dates: chemical composition and fermentation substrate for the production of extracellular catalase by an Aspergillus phoenicis mutant
}

\author{
Kacem-Chaouche N. ${ }^{1}$, Dehimat L. ${ }^{1}$, Meraihi Z. ${ }^{1}$, Destain J. ${ }^{2}$, Kahlat K. ${ }^{3}$ and Thonart Ph. ${ }^{2}$ \\ ${ }^{1}$ Laboratoire de Mycologie, de Biotechnologie et de l'Activité Microbienne (LamyBAM), \\ Faculté des Sciences de la Nature et de la Vie, Université Constantine-1 (25000) Algérie. \\ ${ }^{2}$ Centre Wallon de Biologie Industrielle, Unité Bio-industrie, Gembloux Agro-Biotech, \\ Université de Liège, Belgique. \\ ${ }^{3}$ School of Physiology and Pharmacology, Medical Sciences Building, University of Bristol, \\ Bristol BS8 1TD, UK.
}

\begin{abstract}
The recovery of dates downgraded as a fermentation medium for the production of extracellular catalase by Aspergillus phoenicis K30 was studied. Analysis of the chemical composition of pulp and kernel flour of dates showed that the pulp had a considerably greater carbohydrate content compared to the kernel (84 vs $2.93 \%$ respectively). However, the kernel flour was richer in nitrogen ( $0.68 \%$ vs 0.34$)$, mineral elements (3.63 vs $1.28 \%$ ) and in essential fatty acids C18: 2 vs C18: 3 than the pulp flour. The soluble extract of the date flour showed that sugars solubilised at $90 \%$ consisted of sucrose, fructose and glucose. Therefore, this extract, being an important source of carbon and energy, was used in the current study as a fermentation medium (after supplementation with $20 \%$ of corn steep) for the production of extracellular catalase by $A$. Phoenicis K30. During the course of this fermentation, the biomass was estimated at $18.6 \mathrm{~g} / \mathrm{L}$ after $72 \mathrm{~h}$ of culture, while the maximum concentration of extracellular catalase $(47.5 \mathrm{U} / \mathrm{ml})$ was reached at $96 \mathrm{~h}$ of fermentation. The mycelium obtained in pellet form is suitable for industrial exploitation of this process.
\end{abstract}

Keywords: dates chemistry, ELSD, dates flour, Fermentation, Extracellular catalase, Aspergillus phoenicis.

\section{INTRODUCTION}

The date palm, known scientifically as Phoenix dactylifera of the monocots family, is a dioecious species with several hundred varieties. It grows best between 10 and 39 degrees north latitude in the desert and arid regions. This is because of its resistance to extreme weather conditions including soil lacking organic matter, salinity of about $18 \mathrm{~g} \mathrm{~L}^{-1}$, excessively cold nights and hot days (Munier, 1953).

The Algerian Pheonicicole heritage was estimated in 2002 at more than $13,505.880$ date palms and is characterized by a biodiversity of cultivated varieties including several types known, in Algeria, as Deglet Nour (semi-soft and high quality dates designated for export), Ghers and similar soft dates, and Degla Beida and similar dry dates. The Algerian production of dates in 2002 was estimated at 4.2 million quintals, represented by the three major varieties mentioned above (Anonymous 2003). The Deglet Nour variety accounts for $5,403,140$ trees representing $40 \%$ of the total national number of palm, producing 2.263 million quintals, followed by the Degla beida variety with 5 , 850,680 trees (43\% of the total number of palm) producing 1335 million quintals. Finally, the number of palm dates of the soft variety accounts for $2,252,060$ trees (17\% of the total number of palm) whose production was 0.602 million quintals (Anonymous 2003).

Chemically, the work of Cook and Furr (1953) led to the classification of dates into: a) dates with invertase corresponding to soft dates, b) dates with small quantity of invertase representing the half-soft dates and c) dates without invertase corresponding to dry dates. The varieties rich in invertase contain especially reducing sugars, whereas dry dates contain a significant amount of sucrose and a small 
amount of reducing sugars. The co-workers also showed that all of the aforementioned varieties (soft, semi-soft and dry) contain about $77 \%$ of total sugars. However, these varieties contain different quantities of reducing sugars and sucrose with the soft, semisoft and dry dates, containing $77 \%, 39 \%$ and $17 \%$ of reducing sugars and $0 \%, 38 \%$ and $59 \%$ of sucrose, respectively.

Another classification was suggested by Estanov (1988) who distinguished four classes of dates according to their sugar composition: the first class containing 40 to $65 \%$ sucrose, 20 to $40 \%$ glucose and fructose, and 15 to $25 \%$ water. The second class containing 10 to $35 \%$ sucrose, 40 to $75 \%$ glucose and fructose and 10 to $30 \%$ water. The third class containing 0 to $10 \%$ sucrose, 65 to $90 \%$ glucose and fructose, and 10 to 35 of water. The last class containing $0 \%$ of sucrose, 35 to $75 \%$ of glucose and fructose and $35-65 \%$ of water. Moreover, several studies have revealed the richness of dates in minerals and amino acids (Booiji et al., 1992; Bensalah and Hellali, 2006). However, to our knowledge, the contents of dates in fatty acids has not been reported. In addition, there has not been much research interest in the chemical composition of the kernel of date fruits. Thus, the main objective of this work was to determine the chemical composition of fruit's pulp and kernel of Algerian dates (var. mech Degla). Considering this composition, the use of the soluble extract of date flour as an alternative source of carbon in fermentation medium was investigated for producing extracellular catalase by Aspergillus phoenicis K30.

\section{MATERIALS AND METHODS}

The chemical composition of the dates was sought, separately, in the pulp flour and kernel of the fruit and in their extracts. To establish a reliable comparison, the flours are obtained following the same procedure and under similar conditions.

Preparation of date flour and extract: Dates decommissioned (mech-Degla variety) were pitted and dried at $45-50^{\circ} \mathrm{C}$ in an oven for 4 days. They were then crushed, milled and sifted ( $\phi 1 \mathrm{~mm}$ ). The prepared flour was stored in tightly sealed flacons to minimize hydrolysis enzymatic reactions. To prepare the soluble extract of the date flour, different concentrations were prepared in sealed vials and stirred for 3 hours. The solution was then centrifuged for 1 hour at 4700 rounds/minute (rpm). The supernatant was considered as the Soluble Extract of the date Flour.

\section{Chemical composition of dates}

Determination of moisture: the moisture content was determined on $5 \mathrm{~g}$ of the date flour dried to $130^{\circ} \mathrm{C}$ for 2 hours using the following formula: ( $E$ $m) .100 / E$, where $E$ is the original mass in grams, and $m$ is the mass in grams of the dry sample.

Extraction and determination of sugars: the method used to determine sugar levels was HPLC (HP 1050) coupled with ELSD (Evaporative Light Scattering Detector) (Alteck 500). A standard range was established with $10 \mathrm{ml}$ of each solution of sugar at $1 \%$ (Rhamnose, xylose, arabinose, fructose, glucose, sucrose, maltose and lactose). The sugars were determined in the soluble extract of date flour and in flour. To analyse the extract, $5 \mathrm{ml}$ were placed in a centrifuge glass tube and centrifuged at 7000 rpm for $5 \mathrm{~min}$. $1 \mathrm{ml}$ of the supernatant was added to $4 \mathrm{ml}$ of ethanol followed by vortex mixing for one minute. The solution was centrifuged again at 2000 $\mathrm{rpm}$ for $5 \mathrm{~min}$. $1 \mathrm{ml}$ of the supernatant was transferred into a vial for analysis by HPLC.

The flour was analysed by adding $1 \mathrm{~g}$ to $5 \mathrm{ml}$ of distilled water. The mixture was shaken for 5 minutes followed by centrifugation (7000 rpm for $5 \mathrm{~min}$ ). The rest of the procedure was the same as that described above. The operating conditions of HPLC were the following: the eluting solvent, acetonitrile / water (70/30); injection volume, $5 \mu \mathrm{l}$; the flow rate, $1 \mathrm{ml} /$ min. column type APS 5 Hypersil-2, $250 \times 4.6 \mathrm{~mm}$. ELSD with a column-NH2 (Alteck $-25 \mathrm{~cm}$ ).

Determination of Nitrogen and protein: Analysis was based on the principle Kjeldahl on automated equipment (1030 Kjeltec Auto Analyzer). The percentage of protein is obtained by multiplying the percentage of nitrogen by a factor of 6.25 .

Determination of amino acids: They were determined by an automated device (Amino acids analysis)

Determination of fatty acids: The qualitative and quantitative determination of fatty acids was carried out by gas chromatography. The apparatus used was an HP 5890 Series II under the following conditions: $\mathrm{HP}$ innowax polar column $30 \mathrm{~m} 0.25 \mathrm{~mm}$ d, the carrier gas used was helium $30 \mathrm{~cm} / \mathrm{sec}$, FID detector.

Determination of ashes: 5 grams of the date flour was weighed into a crucible, previously charred and tarred, for incineration. The cup was placed on a hotplate up to charring of the material, and was then placed in a muffle furnace set at $550^{\circ} \mathrm{C}$.

Determination of mineral elements: The mineral elements were determined by atomic absorption (Perkin Elmer, AAnalyst, 1100B) following the 
protocol of Bureau Environnemental et Analyse de Gembloux (BEAGx).

\section{Fermentation:}

Strain: Aspergillus phoenicis $\mathrm{K} 30$ is a mutant strain of Aspergillus phoenicis (Kacem Chaouche et al., 2005), isolated from animal feed, and identified at Mycological, Biotechnological and Microbial Activity Laboratory, Faculty of Life and Natural Sciences, U. Constantine 1. The identification of this strain was confirmed by the Belgian Co-ordinated Collections of Micro-organisms MUCL (Belgium). The spores were maintained in suspension in $30 \%$ glycerol / physiological water at $-20^{\circ} \mathrm{C}$.

Preparation of spores: The production of spores was achieved by inoculation of the strain into a 250 $\mathrm{ml}$ Erlenmeyer flask containing $100 \mathrm{ml}$. Potato dextrose agar (PDA) medium. After incubation for 5 days at $30^{\circ} \mathrm{C}$, a thrust dense black color was developed. The spore suspension was prepared in physiological water then spores were counted under the microscope using a haemocytometer.

Fermentation medium: The production of catalase by Aspergillus phoenicis $\mathrm{K} 30$ was achieved by inoculation of spore suspension $\left(10^{6}\right.$ spores $\left./ \mathrm{ml}\right)$ into $100 \mathrm{ml}$ of medium contained in $250 \mathrm{ml}$ Erlenmeyer flasks. The medium consisted of the following (per litre): $40 \mathrm{~g}$ flour dates (as the extract) supplemented with $20 \mathrm{~g}$ of corn steep liquor, $2.0 \mathrm{~g} \mathrm{Na}\left(\mathrm{NO}_{3}\right)_{2}, 0.25 \mathrm{~g}$ $\mathrm{KH}_{2} \mathrm{PO}_{4}, \mathrm{KCl}$, and $\mathrm{MgSO}_{4}$, and $0.001 \mathrm{~g} \mathrm{FeSO}_{4}$. The $\mathrm{pH}$ was adjusted at 6 . The flasks were incubated at $30^{\circ} \mathrm{C}$ for $144 \mathrm{~h}$ in a rotary shaker at $200 \mathrm{rpm}$. Samples were taken every $24 \mathrm{~h}$. At the end of each incubation period, the fungal mycelium was separated from the culture fluid by filtration through Whatman paper $\mathrm{N}^{\circ} 2$. The filtrate was used for $\mathrm{pH}$ measurement and to study extracellular catalase activity. The mycelium was used to study endocellular enzyme activity and to determine the dry weight.

The activity of extracellular and intracellular catalase was measured in the filtrate (Whatman paper No. 2) according to Caridi et al. (1991) method. The cell extract was obtained by bursting cells by ultrasonic vibration of the mycelium, in a $0.1 \mathrm{M}$ phosphate buffer $(\mathrm{pH} 7.5)$ at $0-4^{\circ} \mathrm{C}$ (Model Sonnifier Main Components 250/450, VWR, Leuven, Belgium). One enzymatic unit $(U)$ of the catalase is defined as the amount of enzyme that catalyzes the breakdown of a $\mathrm{H}_{2} \mathrm{O}_{2}$ mol min- 1 at $25^{\circ} \mathrm{C}$ and $\mathrm{pH} 7.5$. Biomass was estimated by drying the mycelium at $105^{\circ} \mathrm{C}$ until constant weight.

\section{RESULTS}

Chemical composition of dates: The moisture content of the dates was $6.0 \%$ which is relatively low. The total sugars represented about $84 \%$ of the pulp flour (flesh) with $63.83 \%$ sucrose, $19.03 \%$ fructose and $17.13 \%$ glucose. Analysis of the soluble extract of date flour (SEDF) showed that $89 \%$ of the total sugars have been extracted, where sucrose represented $91.52 \%$, fructose $83.7 \%$ and glucose $85.4 \%$ (Table 1 ).

Table 1: Sugar content in dates (var. mech-Degla).

\begin{tabular}{|l|l|l|l|l|}
\hline \multirow{2}{*}{ Sugar } & \multicolumn{2}{|c|}{ Pulp (mg/1g of flour) } & \multicolumn{2}{|c|}{$\begin{array}{l}\text { Kernel (mg/ 1g of } \\
\text { flour) }\end{array}$} \\
\cline { 2 - 5 } & Flour & $\begin{array}{l}\text { Soluble } \\
\text { extract }\end{array}$ & Flour & $\begin{array}{l}\text { Soluble } \\
\text { extract }\end{array}$ \\
\hline $\begin{array}{l}\text { Total } \\
\text { Sugar }\end{array}$ & 834.41 & 742.52 & 29.36 & 7.47 \\
\hline Sucrose & 532.61 & 487.48 & 18.00 & 5.09 \\
\hline Fructose & 158.82 & 132.94 & 5.26 & 1.28 \\
\hline Glucose & 142.98 & 122.10 & 6.10 & 1.09 \\
\hline
\end{tabular}

The analysis of carbohydrates of kernel flour (represented up to $50 \%$ of the weight of the fruit) revealed a low level of total sugars $(2.93 \%$ of the flour weight) with $61.31 \%$ sucrose and 38.69 of reducing sugars. The soluble extract of the flour has retained $64 \%$ of sugars (Table 1 ). On the other hand, the nitrogen content represented $0.34 \%$ of the pulp flour weight, including $2.1 \%$ protein. The concentration of this element was higher in the kernel flour $(0.68 \%$ including $4.3 \%$ protein). However, the soluble extracts of both pulp and kernel contained only traces of this element (Table 2).

Table 2 Contents of nitrogen and protein in dates (var. mech-Degla)

\begin{tabular}{|l|l|l|l|l|}
\hline \multirow{2}{*}{$\begin{array}{l}\text { Nitrogenous } \\
\text { materials }\end{array}$} & \multicolumn{2}{|c|}{ Pulp } & \multicolumn{2}{c|}{ Kernel } \\
\cline { 2 - 5 } & Flour & $\begin{array}{l}\text { Soluble } \\
\text { Extract }\end{array}$ & Flour & $\begin{array}{l}\text { Soluble } \\
\text { Extract }\end{array}$ \\
\hline $\begin{array}{l}\text { Nitrogen } \\
(\%)^{*}\end{array}$ & 0,34 & 0.011 & 0.68 & 0.005 \\
\hline Proteins (\%) & 2.10 & 0.70 & 4.3 & 0.30 \\
\hline
\end{tabular}

(\%) relative to $100 \mathrm{~g}$ of flour.

Because the extracts contained only traces of nitrogen, the amino acid investigation was conducted only on flour. The analysis led to identification of 17 amino acids at different concentrations (Table 3). 
Table 3 Content of amino acids in dates (var. mech-Degla)

\begin{tabular}{|c|c|c|c|c|}
\hline \multirow{3}{*}{$\begin{array}{l}\text { Amino acids } \\
\text { Aspartic acid }\end{array}$} & \multicolumn{2}{|c|}{ Kernel } & \multicolumn{2}{|c|}{ Pulp } \\
\hline & $\mathrm{g} / 100 \mathrm{~g}$ of flour & $\%^{*}$ & $\mathrm{~g} / 100 \mathrm{~g}$ of flour & $\%^{*}$ \\
\hline & 0.329 & 10.0 & 0.135 & 8.7 \\
\hline Threonine & 0.135 & 4.1 & 0.059 & 3.9 \\
\hline Serine & 0.160 & 4.9 & 0.073 & 4.7 \\
\hline Glutamic acid & 0.820 & 25.1 & 0.332 & 21.6 \\
\hline Proline & 0.160 & 4.9 & 0.138 & 9.0 \\
\hline Glycine & 0.194 & 5.9 & 0.119 & 7.7 \\
\hline Alanine & 0.187 & 5.7 & 0.123 & 8.0 \\
\hline Cysteine & 0.029 & 0.9 & 0.024 & 1.6 \\
\hline Valine & 0.206 & 6.3 & 0.086 & 5.6 \\
\hline Methionine & 0.034 & 1.0 & 0.012 & 0.8 \\
\hline Isoleucine & 0.128 & 3.9 & 0.060 & 3.9 \\
\hline Leucine & 0.247 & 7.6 & 0.106 & 6.9 \\
\hline Tyrosine & 0.033 & 1.0 & 0.012 & 0.8 \\
\hline Phenylalanine & 0.151 & 4.6 & 0.062 & 4.1 \\
\hline Histidine & 0.076 & 2.3 & 0.039 & 2.6 \\
\hline Lysine & 0.135 & 4.1 & 0.080 & 5.2 \\
\hline Arginine & 0.246 & 7.5 & 0.078 & 5.0 \\
\hline Somme & 3.270 & & 1.538 & \\
\hline
\end{tabular}

- Percentage relative to all amino acids contained

Table 3 shows that the kernel and pulp flour contains six amino acids in common and in remarkable quantities: Asp, Glu, Pro, Gly, Ala and Leu. However, kernel contains more Arginine and valine. Furthermore, measurement of nitrogen levels showed that the kernel is richer in nitrogen than the pulp. Thus, it can serve as a good source of nitrogen. Quantification of fatty acids was also carried out on the flour of the pulp and kernel. The results showed that the kernel was richer in lipid compared to the date pulp ; this lipid content represented $43.55 \%$ of the weight of the kernel flour, but the pulp flour contained only $0.15 \%$. The pulp flour contains 16 fatty acids, 9 of which were identified as : C12: 0 ,
C14: 0, C15: 0, C16: 0, C17: 0, C18: 0, C18: 1, C18: 2 and C18: 3 . The kernel flour contains 14 fatty acids, 7 of which were identified as : C12: 0, C14: 0, C16: 0, C18: 0, C18: 1, C18: 2 and C18: 3. The special feature of this composition was the existence of two saturated odd-numbered fatty acids: C15: 0 and C17: 0 in the flour of the fruit pulp (var. mech-Degla).

The estimation of ash in the flour pulp and kernel showed that the kernel contains $3.36 \%$ of its weight, while the pulp flour contains only $1.28 \%$ (Table 4). The kernel of dry dates is therefore richer in minerals than the pulp, particularly in iron $(143 \mathrm{mg} / \mathrm{kg}$ ), sodium $(659 \mathrm{mg} / \mathrm{kg})$ and zinc $(131 \mathrm{mg} / \mathrm{kg})$. 
Table 4 Content of mineral elements in dates (var. mech- degla)

\begin{tabular}{|c|c|c|c|c|c|}
\hline Elements & Pulp flour & Kernel flour & Elements & Pulp Extract & Kernel Extract \\
\hline $\mathrm{N}(\%)$ & 0.321 & 0.627 & $\mathrm{NO}_{3}(\mathrm{mg} / \mathrm{L})$ & $<0.1$ & $<0.1$ \\
\hline $\mathrm{Cl}$ & 0.321 & 0.0627 & $\mathrm{Cl}^{-}$ & 35 & 26 \\
\hline $\mathrm{Ca}$ & 0.46 & 0.40 & $\mathrm{Ca}^{2+}$ & 5.55 & 4.11 \\
\hline $\mathrm{K}$ & 0.654 & 0.342 & $\mathrm{~K}^{+}$ & 0.75 & 0.34 \\
\hline $\mathrm{Mg}$ & 0.067 & 0.084 & $\mathrm{Mg}^{2+}$ & 0.61 & 0.51 \\
\hline $\mathrm{P}$ & 0.050 & 0.028 & $\mathrm{PO}_{4}{ }^{2-}$ & 12.9 & 6.0 \\
\hline $\mathrm{Fe}(\mathrm{mg} / \mathrm{Kg})$ & 34 & 143 & $\mathrm{Fe}^{2+}$ & 0.025 & 0.015 \\
\hline $\mathrm{Mn}$ & 3.2 & 9.3 & $\mathrm{Mn}^{2+}$ & 0.03 & 0.03 \\
\hline $\mathrm{Na}$ & 296 & 659 & $\mathrm{Na}^{+}$ & 0.48 & 5.11 \\
\hline $\mathrm{Hg}$ & 0.76 & 0.73 & $\mathrm{Hg}^{+}(\mu \mathrm{g} / \mathrm{L})$ & $<0.01$ & $<0.01$ \\
\hline $\mathrm{Cr}$ & $<1$ & 25 & $\mathrm{Cr}$ & $<1$ & 3 \\
\hline Mo & 2.0 & 1.0 & Mo & $<0.1$ & $<0.1$ \\
\hline $\mathrm{Zn}$ & 57 & 131 & $\mathrm{Zn}$ & 72 & 62 \\
\hline $\mathrm{Ni}$ & $<1$ & 20 & $\mathrm{Ni}^{2+}$ & 12 & 50 \\
\hline $\mathrm{Cu}$ & 6.3 & 13 & $\mathrm{Cu}^{+2}$ & 74 & 57 \\
\hline $\mathrm{Cd}$ & $<0.1$ & 0.1 & $\mathrm{Cd}$ & 0.7 & 1.4 \\
\hline $\mathrm{Pb}$ & 2.7 & 1.6 & $\mathrm{~Pb}$ & 17 & 6 \\
\hline
\end{tabular}

Date flour extract: fermentation substrate for the production of catalase: The flour soluble extract of date pulp (FSED) was used as a fermentation medium for the development $A$. phoenicis K30 and for production of extracellular catalase. The FSED contained a high content of sugars dissolved by our extraction process $(90 \%$ of existing content in the raw material, pulp). Intracellular catalase had been produced before $24 \mathrm{~h}$ of fermentation, while extracellular catalase began to be measurable after this time point (Fig 1). The maximum extracellular catalase activity (47.5 U.ml-1) was obtained after 96 $\mathrm{h}$ of growth and the best cell dry weight $(18.6 \mathrm{~g} / \mathrm{L})$ was estimated at $72 \mathrm{~h}$ of fermentation (Fig.1). In addition, this medium composition has allowed $\mathrm{pH}$ stability during the fermentation period. Further, the quantity of the produced enzyme and biomass are relatively high compared with those obtained by the strain under the same conditions on a synthetic medium containing $80 \mathrm{~g} / \mathrm{L}$ of glucose (as a source of carbon) and $3 \mathrm{~g} / \mathrm{L}$ peptone; Our results showed that the maximum biomass $(16.2 \mathrm{~g} / \mathrm{L})$ was recorded after $48 \mathrm{~h}$ of fermentation accompanied by an extra cellular catalase activity of up to $25.75 \mathrm{U} / \mathrm{ml}$ at $54 \mathrm{~h}$ of culture.

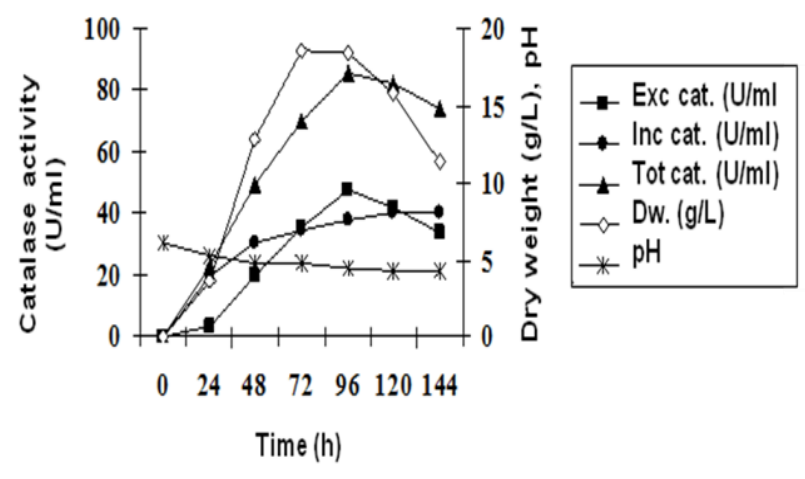

Fig. 1. Catalase production and changes in pH during the development of $A$. phoenicis in $250 \mathrm{ml}$ Erlenmeyer flasks containing $100 \mathrm{ml}$ of supplemented soluble

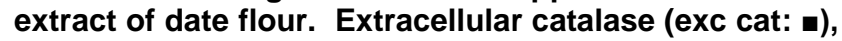
intracellular catalase (inc cat: $\bullet$ ), total catalase (tot cat: $\Delta)$, dry weight (dw : $\diamond)$, and $\mathrm{pH}\left(^{*}\right)$. 


\section{DISCUSSION}

The dry dates (var. Mech-Degla) used in this study were very firm, easily stored and could be transported without any deterioration in form or constituents. The results of chemical analysis show that the dry pulp of dates contained $84 \%$ sugar of which 65\% sucrose and 35\% reducing sugars (fructose, glucose). In addition, we found that storing the dates for longer increased their sucrose content. The nitrogen and lipids content was very low in the dry date pulp. However, its mineral composition was considerably high. These findings are in agreement with those reported previously by several groups (Cook and furr, 1953; Maier and Shiller, 1960; Souci et al., 1994; Belguedj, 1996, Bensalah and Hellali, 2006). Compared to the pulp, the kernel composition showed an important content in fat, nitrogen (amino acids and proteins) and in minerals. The lack of data on the composition of the date's kernel did not allow us to make comparisons. The simple method of extracting the date flour (pulp and kernel), applied in our research, led to recovery of the majority of sugars $(90 \%)$, which was expected, because the sugars found are soluble in water. $A$. Phoenicis K30 was grown on the proposed medium (flour containing $84 \%$ sugar, supplemented with $20 \%$ of corn steep liquor) in the form of small pellets. This resulted in producing a large biomass $(18.6 \mathrm{~g} / \mathrm{L})$ and extracellular catalase activity $(47.5 \mathrm{U} / \mathrm{ml})$. A few rapports have been published on the production of extracellular catalase by Aspergillus niger on a synthetic medium (Nishikawa et al. 1993, Gromada and Fiedurek 1997). However, to our knowledge, no work has been published on the production of extracellular catalase by fungi on natural media composed essentially of date extract. In addition, it is interesting to point out, following our process, that the dry dates constituted approximately $60 \%$ of pulp at $5 \%$ moisture and contained a yield of $55 \mathrm{~kg}$ of flour per quintal, which gives $462 \mathrm{~kg}$ of total sugars per ton of dry dates. We can conclude that 1 kilogram of this date flour produced $1,187.5 \mathrm{U}$ of extracellular catalase after $96 \mathrm{~h}$ of fermentation. Thus, the proposed medium is an excellent alternative for rapid development of the fungal strain followed by a significant production of easily separable extracellular enzyme. These properties provide an economical and industrial advantage.

\section{CONCLUSION}

To conclude, it appears that the edible part (pulp) of dry dates (var. mech Degla) is rich in carbohydrates representing $84 \%$ of its weight and constituted by $63 \%$ sucrose, $19.03 \%$ fructose and $17.13 \%$ glucose. The mineral content was high when the ash was $1.28 \%$ weight. However, the nitrogen content was low $(0.34 \%)$ with $2.1 \%$ protein. The same was true for fat $(0.15 \%)$. The chemical composition of the kernel was rich in fat $(43.55 \%)$, minerals $(3.63 \%)$ and nitrogen $(0.68 \%$ including $4.3 \%$ protein). However, its content was low in carbohydrates (3.93\%). The extraction process of the flour of the two parts of dates, applied in our research, led to recovery of the majority of sugars $(90 \%)$, as was expected, because the sugars found are soluble in water. This extract, when supplemented, served as a fermentation medium for the production of extracellular catalase by A. phoenicis K30. Moreover, we note that 1 kilogram of date flour produced $118,750 \mathrm{U}$ of easily separable extracellular enzyme after $96 \mathrm{~h}$ of fermentation. This interesting medium can therefore be a preferred alternative for production of both biomass and easily separable extracellular catalase, making this economical medium of great industrial value.

\section{REFERENCES}

Anonyme (2003). Données chiffrées $N^{\circ} 04$, les palmiers dattiers en Algérie, Sous direction des statistiques agricoles, Ministère de l'Agriculture et de Développement rural (Algeria).

Belguedj, M. (1996). Caractéristiques des cultivars de dattiers du nord-est du sahra Algérien. Bulletin spécial de l'Institut National de la Recherche Agronomique d'Algérie (INRAA), 1 : 3-67.

Bensalah, M., Hellali, R. (2006). Composition chimique des fruits de 15 cultivars tunisiens de palmier dattier (Phoenix dactylifera L.). PGR News letter, 148 :19-25.

Booij, I., Piombo, G., Risterucci, A.M., Coupé, M., Thomas, D. and Ferry, M. (1992). Etude de la composition chimique de dattes à différents stades de maturité pour la caractérisation variétale de divers cultivars de palmier dattier (Phoenix dactylifera L.) Fruits, 47 (6): 667-678.

Botton, B., Breton, A., Fevre, M., Gauthier, S., Guy, Ph., Larpent, J.P., Reymond, P., Sanglier, J.J., Vayssier, Y. and Veau, P. (1990). Moisissures utiles et nuisibles, importance industrielle. $2^{\text {th }}$ edn. Masson, Paris.

Caridis, K.A., Christakopulos, P. and Macris, B.J. (1991). Simultaneous production of glucose oxidase and catalase by Alternaria alternata. Appl. Microb. Biotechnol. 34 : 794-797.

Cook, J. and Furr, A. (1953). Relation between the nature and amount of sugars and texture of some varieties of dates cultivated in USA. Processing American Society Horticultural Sciences. 61: 286-292. 
Estanove, P. (1988). Valorisation de la datte. Rapport annuel. Centre de Coopération Internationale en Recherche Agronomique pour le Développement et I'Institut de Recherche sur les Fruits et Agrumes, Paris.

Gromada, A., Fiedurek, J. (1997). Selective isolation of Aspergillus niger mutants with enhanced glucose oxidase production. J. Applied Microbiol. 82 : 648-652.

Noreddine Kacem-Chaouche, Zahia Maraihi, Jacqueline Destain and Philippe Thonart (2005). Biotechnol. Agron. Soc. Environ. 9 (3), 173-178.

Maier, V.P. and Sciller, F.H. (1960). Studies on domestic dates. Food Tchnol. 14 (3) : 139-142.
Moor, H.E.J. and Uhl, N.W. (1982). Major trends of evolution in palms. Bot. Rev. 48: 1-69.

Munier, R. (1953). L'origine du palmier dattier. Fruits. 8(2) : 47-52.

Muzino, T.and Mikaim, V. (1958). Carbohydrates of dates. J. Agric. Chem. Society, Japan. 32 : 829-832.

Nishikawa, Y., Kawata, Y. and Nagai, J. (1993). Effect of triton $\mathrm{X}-100$ on catalase production by Aspergillus terreus IF06123. J. Ferment. Bioeng. 76 : 235-236.

Souci, S.W., Fachmann, W. and Kraut, H. (1994). Food comparison and nutrition table, (5ème éd). Edition Mcd Pharm Scientific Publisher, Stuttgart. 